\title{
Novel Coronavirus (covid-19) a Ubiquitous Hazard to Human Health: A Review
}

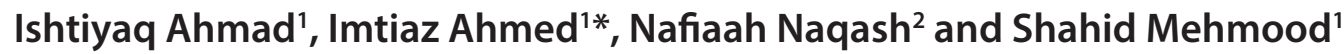 \\ 'DST Sponsored Fish Nutrition Laboratory, Department of Zoology, University of Kashmir, Srinagar, \\ Jammu and Kashmir - 190 006, India; imtiazamu1@yahoo.com \\ 2Department of Zoology, School of Bioengineering \& Biosciences, Lovely Professional University, \\ Phagwara - 144411, Punjab, India
}

\begin{abstract}
Coronavirus (CoV) belongs to the genus beta coronavirus with its high mutation rate within the family Coronoviridae. The virus is extremely transmittable and its pathogenicity caused infection like SARS-CoV-2. An epidemic of this novel coronavirus was first documented in Wuhan, Hubei province of China in December 2019 and is thus called as COVID-19. A series of pneumonia reports were confirmed and now the cases are escalated throughout the world. Although transmission of this virus from animals to humans is rare, however this new strain most likely came from bats and pangolins. COVID-19 has infected more than 4.5 million people $(4,543,060)$ as of May $15^{\text {th }} 2020,09: 50$ GMT worldwide and rises continuously, caused the death of 303,707 so far. Till date no vaccine is available to combat this dreadful virus. Though, certain antiviral drugs have being assisted against COVID-19, which results some success. With the fast spread all over the world, fear and panic is gripping people around the globe. It leads to social stigma towards affected people and physiologically hurts by creating more fear. Need of the time is the collective efforts of all developed countries along with WHO to fight against this dreadful virus. The frontline clinicians, public health authorities and epidemiologists must need to come together to stop this infection and save the precious lives. Since the present virus is new to science, therefore in this review, an attempt has been made to establish some facts related to this novel coronavirus from the existing literature.
\end{abstract}

Keywords: Coronaviruses, COVID-19, Outbreak, Pandemic, Vaccine

\section{Introduction}

Corona is derived from a Latin word which means crown. Coronaviruses were first discovered in 1960s in bronchitis in chicken and two type of viruses in humans, suffering from influenza ${ }^{1,2}$. CoVs belongs to the genus corona virus in the family Coronoviridae $e^{3,4}$, which represents the larger family of viruses that cause illness starting from the communicable disease to severe diseases like MERS$\mathrm{CoV}$ and SARS-CoV'. An microscopy observation revealed that all CoVs are pleomorphic RNA viruses characteristically containing a crown-shape peplomers with having $80-160 \mathrm{~nm}$ and $27-32 \mathrm{~kb}$ positive polarity ${ }^{6-8}$ (Figure 1). The diameter of virus particle is about $120 \mathrm{~nm}^{9}$. The genome encompasses a 5 methylated cap and a 3 polyadenylated tail ${ }^{9}$. As per the newest International Committee of Taxonomy of Viruses (ICTV) classification, there are seven strains of human corona viruses, which include 229E, NL63, OC43, HKU1, Middle East Respiratory Syndrome (MERS-CoV), Severe Acute Respiratory Syndrome (SARS-CoV) and novel corona virus (Covid-19) consisting of thirty-eight unique species within the subfamily ${ }^{10}$ accountable for the infection with special relation to the involvement of the respiratory tract like communicable disease, pneumonia, bronchitis, pharyngitis, sinusitis and lots of other symptoms like occasional watery and diarrhea ${ }^{11,12}$. The quantity of species may still increase, as there are several unclassified $\mathrm{CoVs}^{13}$. CoVs cause disease in a very sort of domestic and wild animals in addition as in humans, where $229 \mathrm{E}$

${ }^{*}$ Author for correspondence 


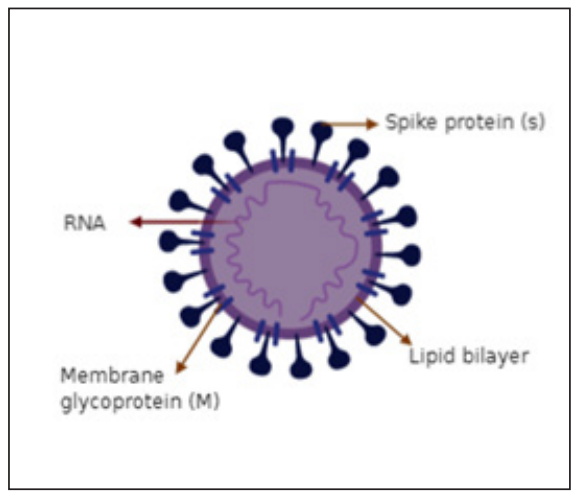

Figure 1. Structure of SARS-CoV-2.

and NL63 CoVs infect mammals and OC43 and HKU1 $\mathrm{CoVs}$ mainly infect birds ${ }^{14}$. Two highly pathogenic CoVs, SARS-CoV outbreak started in 2003 in Guangdong province of China and MERS-CoV started in 2012 in Saudi-Arabia have caused epidemics in past ${ }^{6,11,15-18}$, and now a novel coronavirus (COVID-19) could be a new strain that has not been previously identified in humans. WHO declared it (nCoV) as zoonotic that's they are transmitted between animals and people. The severity of fast spreading from China to all over the globe has affected 210 countries and territories till date. An appearance of SARS-COV in humans has turned up as a core study within the field of research. Hence, during this review the data from past/present studies on novel corona virus are collectively discussed to decipher the extent of this recent outbreak. Unavailability of effective treatment declares preventive measures to limit the spread as current strategy. Therefore the modes of prevention have also been discussed. Overall this review focused on the origin of COVID-19, the immense requirement of vaccine and also the preventive strategies to regulate the pandemic.

\subsection{Origin and Spread of Covid-19}

A novel coronavirus outbreak was first recognized in Wuhan, Hubei province China in December 2019, wherein a series of pneumonia cases were confirmed ${ }^{19-21}$. Many of the initial cases had common exposure to the Hunan wholesale seafood market that also traded live animals. The closed-circuit television was generated and respiratory samples of patients were sent to reference labs for etiologic investigations ${ }^{22}$. On 31 st December 2019, China reported the outbreak to the World Health Organization (WHO) and on $1^{\text {st }}$ January the Huanan sea food market was closed. It had been announced by the
Chinese authorities on January 7, 2020 that a new type of Corona virus (novel Corona virus, $\mathrm{nCoV}$ ) has been isolated ${ }^{23}$. This virus was named as $2019-\mathrm{nCoV}$ by WHO on January $12^{\text {th }}$ and COVID-19 on $11^{\text {th }}$ February 2020. On $11^{\text {th }}$ March, 2020, the World Health Organization (WHO) declared Covid-19 an endemic, a public health emergency of international concern. Therefore, it's highly urgent to determine the vaccine for the treatment of this virus. Ecological samples from the Hunan seafood market are taken which showed positive results, indicating that the virus may have originated from there ${ }^{23}$. It has been recorded that the number of positive COVID-19 cases started increasing day by day even in those persons who were not directly exposed to an animal market, signifying human to human transmission of this viral infection ${ }^{24}$. The infection due to COVID-19 was so dreadful that it began to become fatal and also the first death in China occurred on $11^{\text {th }}$ January, 2020. Later on the virus began spread to other cities of China rapidly because of the people travelling from Wuhan city to rest of the places. Soon the whole city of Wuhan with population of around 11 million was put to sleep lockdown with complete restrictions at entry and exit points. The disease became so fatal that around 100 deaths were reported within 24 hours in China, which led to the lockdown of entire country. Rest of the countries began to evacuate their citizens stranded in China and the airports were kept under medical screening. Unfortunately, the intensity of spreading COVID-19 virus was so fast that the Asian as well the European countries became prey to this dreadful disease. On March 13, Europe was declared as new epicenter of Covid-19 by WHO due to immense spread throughout the European countries. As a result, all the countries began to take precautionary measures by testing every citizen who had a travel history to China and were put under quarantine for 14 days as it has been reported that the incubation period of this virus is 2-14 days ${ }^{19,25}$.

Subsequently the confirmed cases began to increase day by day throughout the entire world. Among 195 countries the virus spread drastically to 187 countries all over the globe. As of $15^{\text {th }}$ May, 2020, quite 4.5 million positive cases worldwide were confirmed with USA as the epicenter with $1,457,593$ positive cases, whereas the continent wise data are presented in Figure 2. It has been reported that slowly the number of positive cases as well as the fatalities in China began to decline with an exponential increase in other countries like South Korea, Iran, Italy, Spain, USA etc. However till $15^{\text {th }}$ May, 2020 


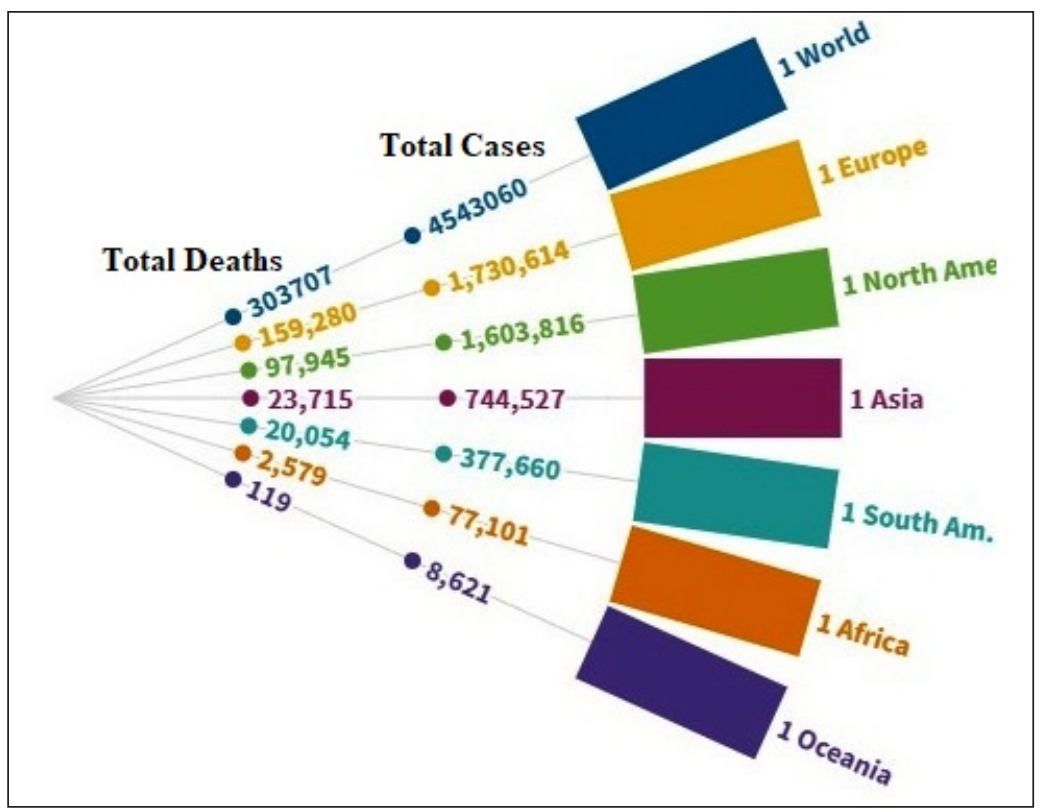

Figure 2. World wide data (Continent wise) on COVID-19 till $15^{\text {th }}$ May, 2020 09:50 GMT.

USA became the worst hit country exceeding the number of fatalities $(86,912)$ over Spain, Russia, UK, Italy, China as well as rest of the countries.

\subsection{Life Cycle of Covid-19}

The life cycle of corona virus starts when the viral entry into target cells is performed by spike (S) envelope glycoprotein, which mediates both host cell receptor similarly as membrane fusion ${ }^{26}$. It was found that SARS corona virus gets entry into the cell either through membrane fusion or via endocytic pathway and delivers its genetic material ${ }^{5,26-28}$. The sites of receptor binding domains within the $\mathrm{S} 1$ region of a coronavirus $\mathrm{S}$ protein varied depends upon the virus, with having RBD at $\mathrm{N}$ terminus of S1 (MHV), while others (SARS-CoV) have the RBD at $\mathrm{C}$ terminus of $\mathrm{S} 1$ region ${ }^{29,30}$. The protease of the host cell cleaves and activates the receptor attached spike protein. Then due to cleavage and activation, virus enters into the host cell by the process of endocytosis or by direct fusion of the viral envelope to the host cell ${ }^{31}$. The mechanism of its replication has been thoroughly analysed in Vero E6 cells. After fusion nucleic acid replication and protein synthesis occurs which results in assembling $\mathrm{N}$-protein and genomic RNA in rough endoplasmic reticulum (RER). The formation of nucleocapsid and its increased number induces swelling of RER. The ribosomes attached to the surface of RER were reported to disappear over time with the increase in nucleocapsids. The structure formed reflected the virus morphogenesis matrix vesicae $(\mathrm{VMMV})^{32}$. Parallel to ribosomal disappearance Golgi apparatus swells forming smooth vesicles. The VMMV formed releases the nucleocapsids into these smooth vesicles wherein they acquired the envelopes. This completes the assembly of virions and finally the last phase where smooth vesicles move towards the cell membrane. Finally the smooth vesicles combine with the cell membrane releasing virions ${ }^{33}$. The virus has been reported to exploit the host cell mechanism by replicating and spreading throughout.

\subsection{Sources and Mode of Transmission}

Coronaviruses are commonest in certain species of animals like cattle and camels. Although the transmission of corona viruses from animals to humans is rare, this new strain likely came from bats ${ }^{15,34}$, though one study suggests pangolins could even be the origin of this virus. However, it remains still uncertain exactly how this virus first transmitted to humans. Some reports trace the earliest cases back to a seafood and animal market in Wuhan and reported that may be from there SARSCoV-2 began to spread to humans. Recently the invention of several lineages of pangolin corona virus and their similarity to SARS-CoV-2 has been reported which suggests that pangolins could be the possible hosts within 
the emergence of novel corona virus ${ }^{35}$. They also observed phylogenetically that these novel pangolin corona virus genomes have almost $85.5 \%-92.4 \%$ sequence similarity to SARS-CoV-2, represents two sub-lineages of SARSCoV-2 related viruses, of these one is extremely much closer to SARS-CoV-2 $2^{35}$. Though it is thought to be originated from bats but the intermediary animal sources are utterly unknown. A current research study revealed the susceptibility of animals to corona virus in close contact with humans. It was observed that replication of SARS-COV-2 was poor in dogs, pigs, ducks and chickens. However ferrets and cats were found susceptible to airborne infection ${ }^{36}$.

It has been earlier reported that human corona viruses may have originated from palm civets for SARS-CoV ${ }^{37-39}$, while for MERS-CoV from camel ${ }^{40-42}$. However, advanced scientific outcomes have confirmed that bats are the main reservoir host for both SARS-CoV and MERS CoV prior to these viruses infect the human body, as they use other animals for intermediate hosts ${ }^{20,43-47}$. Moreover, it has been reported that the novel corona virus, which is now became pandemic resembles the samples taken from the coronavirus isolated from bats. These findings have been confirmed by trading of wild animals for human consumption from Huanan sea food market, where the first cases appeared ${ }^{48,49}$. After ten days, several secondary cases began to be reported but had no direct contact with Huanan sea food market, indicating that the transmission was taking place from human to human.

Primarily the infection spreads when an infected person get in touch with non-infected person by coughing or sneezing ${ }^{26,50}$ and they spray minute liquid respiratory droplets from their mouth or nose, which may possibly contain virus causing infection to other people ${ }^{51}$. These infected droplets may spread upto 1-2 m and can deposit on ground and other solid surfaces which can remain feasible on these surfaces for several days in any atmospheric conditions $s^{51-57}$. Also when an infected person gets in touch with surfaces without any protection and then normal person coming in contact with such surfaces is one of the main reasons of transmission ${ }^{58,59}$ (Figure 3). However, some common disinfectants such as Sodium hypochlorite, hydrogen peroxide and few more can destroy it in less than a minute ${ }^{60}$. Whether infectivity be able to occur through oral or conjunctive routes is still unidentified, but Covid-19 has been detected in tears ${ }^{61}$, which is identical to SARS-CoV ${ }^{62}$. Also it can occur from asymptomatic person as well as before the onset of symptoms $s^{63}$, which is the main hurdle to stop this virus through communication. During the initial phase of this disease, several symptoms of severe acute respiratory infection occurs, with some patients hurriedly emerging acute respiratory distress syndrome (ARDS) and other severe complications, which ends in multiple organ failure ${ }^{64}$, especially in those patients who are more fatty than normal people or having diabetes, heart and other problems. The older patients have reported severe alveolar damage leading to respiratory failure ${ }^{65}$. In certain reports patients are suffering from cardiovascular damage that may even lead to heart failure ${ }^{25}$. Infection can occur by inhaling of those droplets or touching surfaces contaminated by them or then touching the nose, mouth and eyes. In addition to this, virus has been found in the stool and contamination of the water supply and consequent transmission via aerosolization/feco oral route is also hypothesized ${ }^{66}$. According to Chen et al. ${ }^{64}$ nine pregnant women with COVID-19 in the third trimester, amniotic fluid, cord blood and neonatal throatswab samples have been collected from six patients which showed negative results for COVID-19, signifying there was no substantiation of intrauterine infection caused by vertical transmission in women who developed COVID-19 pneumonia in late pregnancy. Although four premature babies were born and among them, no one was directly related to COVID-19 infection. Till date no information is accessible on perinatal outcome when the infection is acquired in the first and early second trimester of pregnancy, which should be monitored vigilantly after recovery. Furthermore, it is clear that there is no risk of vertical transmission through breastfeeding. However, it has been observed that this virus is transmitted via close contact and currently in China all newborn babies are being alienated from their infected mothers for at least 14 days, which made direct breastfeeding impracticable. However, mothers are being advised to utter their breast milk so as to keep up milk production. Once their test comes negative for COVID-19, they are then capable to breastfeed their infants. Moreover another study by Zheng et al. ${ }^{67}$ reported that the receptor, angiotensin-converting enzyme 2 (ACE2) of novel coronavirus has low expression in almost all cell types of the early maternal-fetal interface, suggesting that there may be no cells that are potentially prone to COVID-19 in maternal-fetal interface. Hence, it is apparent that novel coronavirus infection throughout the time of pregnancy cannot go ahead to transplacental vertical transmission. 


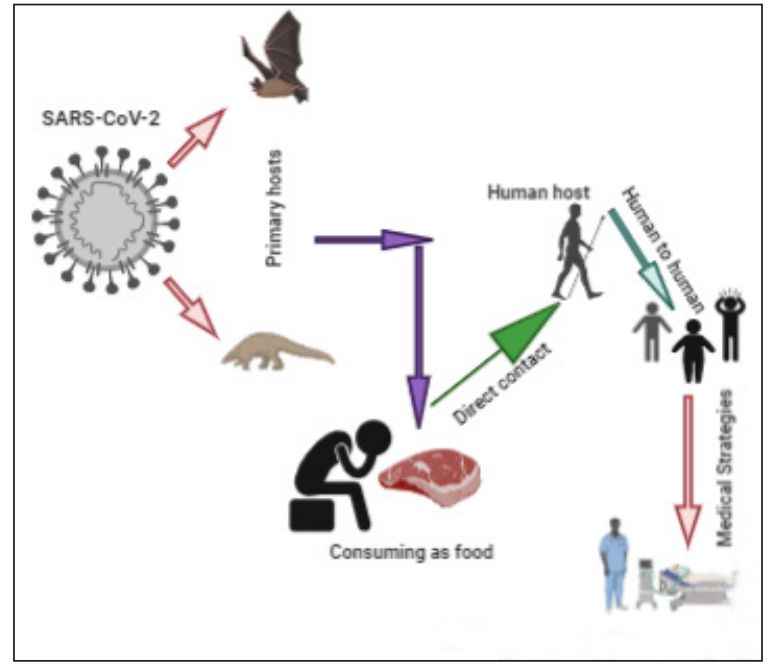

Set: Transmission cycle of SARS-CoV-2.

\subsection{Myths about Covid-19}

(a) People believe that hot water or cold water can kill the virus.

There is no such reason to believe. The most effective and best way is to wash hands frequently with soap and water or cleaning hands with alcohol-based sanitizer (WHO).

(b) It is believed that Covid-19 might be transmitted in those areas with hot and humid climate.

From the findings so far, it is obvious that Covid-19 is transmitted in all those areas with hot and humid weather (WHO).

(c) Earlier it has been speculated that Mosquito bites are also believed to be responsible for transmitting the virus.

To date there is no data nor any evident to support that might the corona virus be transmitted by mosquitoes.

(d) U.V disinfection lamps are believed to kill the novel corona virus.

As UV radiations cause skin irritation, so UV lamps are not recommended to sanitize hands or other areas of skin (WHO).

(e) Spraying alcohol based sanitizer or chlorine all over the body kills the novel virus.

Exposing body to such substances can be harmful to mucous membranes (i.e. eyes, mouth). Both can be useful to disinfect surfaces, but under suitable recommendations.

(f) Vaccines against Pneumonia protect us from the novel corona virus.

Till date no such vaccine has been discovered by scientists. Hence, vaccines against pneumonia like pneumo- coccal vaccine and Homophiles influenza type B (Hib) vaccine are not recommended to cure covid-19 (WHO).

(g) Gargling and rinsing mouth and nose with saline water can protect infection with novel Covid-19.

There are some facts that regularly rinsing or gargling mouth and nose with saline water might help people to recover quickly from common cold. But such suggestions are not recommended to prevent corona virus infection (WHO).

(h) Eating garlic is believed to prevent infection with novel corona virus.

Garlic is considered as a healthy food with antimicrobial properties, but garlic cannot prevent the outbreak of Covid-19 (WHO).

(i) Only old people are prone to this virus.

Corona virus knows no boundaries; it can infect old, young as well as in children. However, people of old age and with pre-existing medical complications (asthma, diabetes, high blood pressure, heart disease, kidney failures etc.) are more susceptible to become severely ill with the virus and may even lead to death. Hence, WHO advises all people of all age groups to take precautionary measures.

(j) Are there any specific medications or vaccines to prevent the novel covid-19.

Every country is in an effort to find some drugs which can treat new deadly virus, but no one has been able to recommend the drug to prevent or treat the infection. Specific treatments throughout the entire world are under exploration, and will be tested through scientific trials. The WHO is also helping to speed up research and advance efforts with a range or partners.

\subsection{Preventive Measures}

The unavailability of specific antiviral treatment for COVID-19 signifies the current strategy to limit the spread. Therefore certain control measures must be focused to reduce the ongoing pandemic. Certain organizations like WHO have issued the recommendations which need to be adopted to prevent the transmission of the pathogen. The patients must be kept in isolation with strategies to control the infection. People must avoid close contacts with the patients suffering from acute respiratory infection. Strict hygiene measures like frequent hand washing is a better option to avoid the spread especially after contact with the infected environment. People should use portable hand sanitizer and air borne precautions like N95 or FFP3 masks. Coughs and sneezes must be covered using disposal tissues. Further the public gatherings must be avoided for the control and prevention of infection. The individuals 
of health care department are at utmost risk therefore the PPE kits and protective masks must be utilized while treating the patients. The international spread of COVID-19 could have been prevented by quarantining the individuals instead of temperature screening which was not enough to detect the disease. To control human to human transmission home quarantine is now treated as the best option as countries failing to maintain proper social distancing by enforcing lockdown faced severity and disastrous outbreak. Therefore the restrictions on travel and maintaining social distancing are mandatory to prevent the spread of corona virus. Besides all this an effective vaccine is the ultimate solution to the ongoing pandemic.

\subsection{Symptoms}

The United States Centers for Disease Control and Prevention have reported wide range of symptoms which may appear 2-14 days after exposure. The infected people have the symptoms ranging from mild to severe illness. Initially individual suffers from the flu like symptoms followed by dry cough. A week later symptoms like difficulty in breathing or shortness of breath appears which requires hospital treatment. Further symptoms like repeated chills, muscle pain and headache can appear. In elderly patients these symptoms may lead to pneumonia with chest pain. Running nose, sneezing or sore throat has been rarely observed in COVID-19 patients. COVID19 infected individuals with preexisting hypertension, diabetes, cardio-vascular and chronic respiratory diseases are at higher risk. Recently loss of taste and smell has also been observed in the hospitalized patients. In china the clinical symptoms were differentiated according to the severity of disease. In mild diseased patient's conditions like non pneumonia and mild pneumonia were observed. The severe patients of COVID-19 reported dyspnea with reduced respiratory frequency. In case of critical patients COVID-19 caused respiratory failure followed by multiple organ dysfunction ${ }^{68}$. Therefore COVID-19 may be present with different stages of clinical symptoms and it's the severity of disease that refers the diagnostic criteria accordingly.

\subsection{Diagnosis}

The diagnosis of covid-19 patients is mainly dependent on the epidemiological history or local transmission. The suspected patients are diagnosed with clinical manifestations including fever, cough and sore throat. However certain cases were found to be asymptomatic and even with normal body temperature. Therefore certain auxiliary observations are mandatory for specific diagnosis. After the COVID-19 outbreak china launched real-time quantitative polymerase chain reaction (RT-qPCR) kits for nucleic acid detection. The RT-qPCR has been reported to have sensitivity of 50-79\% to detect SARS-COV ${ }^{69}$, thus detection rate needs to be improved for diagnosing SARS-COV-2. Low detection rate of RT-qPCR made clinicians to endorse CT scan as mandatory auxiliary diagnostic method. Further it has been observed that the severity of diseased patients can be diagnosed early using high resolution CT (HRCT) ${ }^{70}$. However it is very complicated to distinguish COVID-19 from other viral infections by CT scan imaging. Recently immune identification technology using kits of enzymelinked immunosorbent assay (ELISA) and Point-of-care Testing (POCT) of IgM/IgG have been pretested and reported higher detection rates. Therefore studying the sensitivity of specific auxiliary methods is mandatory for the diagnosis of SARS-COV-2.

Furthermore, the differential diagnosis of COVID-19 is necessary which may include the possibility of different infectious and non-infectious respiratory diseases. It is not possible to differentiate COVID-19 from certain respiratory disorders including influenza, parainfluenza, adenovirus, respiratory syncytial virus and bacterial infection $^{71}$. Therefore differential diagnosis of common respiratory disorders must be evaluated in case of suspected patients.

\subsection{Treatment of COVID-19}

As far as treatment is considered, till date no vaccine is available. Even researchers throughout the world are continuously working on this novel virus to find out a drug. Oxygen therapies and mechanical ventilation are the major treatments for COVID-19 patients. Based on previous data indicating lower mortality rates in patients infected with SARS, the National health commission of China recommended the use of IFN- $\alpha$ and lopinavir/ ritonavir $^{72}$. Despite the unknown effect on covid-19, the health care staff in China has also used a neuraminidase inhibitor, Oseltamivir for suspected patients. There are various reports about the potential treatments for COVID19, which includes Japanese conglomerate Fujifilm who promotes a drug known as favipiravir, and use of 
common anti-malaria drug hydroxychloroquine has been permitted by US Food and Drug Administration, but as per WHO, to date, there is no specific medicine to prevent or treat COVID-19. Even WHO highlighted that many health officials are testifying some of the most hopeful drugs to fight COVID-19, which includes chloroquine and hydroxychloroquine, combination of HIV drugs and a combination of those drugs plus interferon-beta. Remedesivir directly inhibits RNA-dependent RNA polymerase from SARS-CoV-2 with high potency ${ }^{73}$. Remdesivir alone or in combination with another drug i.e., chloroquine or interferon beta considerably blocked the SARS-CoV-2 replication and patients were declared as recovered ${ }^{19,74,75}$. However, Remdesivir is not largely available for the treatment of large number of COVID19 patients in less time, therefore Chloroquine can be proven the drug of choice for its low cost and easily available $^{76}$. Several other combinations of antiviral or antibiotics along with traditional Chinese medicines were also evaluated against COVID-19 in mice as well as in humans ${ }^{74}$. A team of doctors in Shanghai separated the blood plasma from covid-19 recovered patients and the same were injected it in the infected covid-19 patients, who showed positive outcome with rapid recovery ${ }^{77}$. Researchers have found two drugs abidol and darunavir which inhibited coronavirus in vitro cell experiments ${ }^{78}$. Recently, choloroquine and hydroxychloroquine along with paracetamol have been found to be proficient on SARS-CoV-2 in Chinese COV-19 patients $^{79}$. They suggested that COVID-19 patients can be treated with hydrochloroquine along with azithromycin in order to cure their infection and to maximum the transmission of the virus to other people in order to restrain the spread of COVID-19 in the world. The latest guidelines included IFN- $\alpha$, lopinavir, ritonavir, choloroquine phosphate, hydroxychloroquine, ribavirin and arbidol drugs are potentially effective in combating COVID-1980. Further several clinical trials are being performed to confirm the safety and efficiency of these drugs.

It has been reported that certain trials of plasma donation from recovered patients against COVID-19 are being conducted. These trials are similar to that of SARS$\mathrm{COV}^{81}$ and MERS-COV ${ }^{82}$. Severe and acute COVID-19 patients have acquired favorable results. Moreover, the uncomplicated path to neutralize COVID-19 can be the recombinant human monoclonal antibodies. The particular human monoclonal antibody, CR3022 can efficiently bind with the receptor domain of SARS-COV and therefore it can be suggested as therapeutics for SARS-COV- ${ }^{83}$. The alternative monoclonal antibodies for the treatment of positive COVID-19 patients may include m396 and CRR3014 as they have been reported to neutralize SARS-COV ${ }^{84}$. Also, trials of certain vaccines are in pipeline against COVID-19 like U.S National Institute of Allergy and Infectious diseases is preparing a mRNA based vaccine ${ }^{85}$. Chinese Centre for Disease Control and Prevention (CDC) is also working on the progress of an inactivated virus vaccine ${ }^{86,87}$. Scientists in Australia have also started testing two promising coronavirus vaccines in "milestone" lab trials. The first results from the animal tests might be come out as early as June, the scientists said. If successful, vaccines could then be moved into scientific trials that could be conducted at several labs. More recently an Ivermectin drug approved by FDA has been found to have extensive spectrum anti-viral activity which is an inhibitor of the COVID-19 virus, which has proven in lessening in viral RNA load at $48 \mathrm{~h}^{87}$.

Although researchers throughout the world are working very hard to look into the key features, pathogenesis and treatment options, it is very important to focus on therapeutic options as well as cross-resistance of other vaccines. Much more efforts to explore clinical and laboratory evidences are required to target SARSCOV-2. Hence the requirement of specific treatment is urgent for the achieving 100\% curative effect.

\section{Conclusions}

As per the current situation there is an immense need to discover an efficient vaccine for the treatment of this disease/virus. At the moment the only best/safe measures taken by almost all countries to put lockdown the areas including isolating the people with travel history to affected areas, early detection, diagnosis and effective treatment. Continuous monitoring and early attention is mandatory to stop the further spreading of infection. The leaders and health authorities need to ensure that enough facilities are provided to fight against this virus. Once infected, the person must be isolated and provided with optimized care to reduce the possibility of transmission. The awareness and proper guidance must be endorsed among the population to lower the devastating effects. Beyond the endless efforts of scientists around the world the pandemic has reached at its peak. The only weapon in hand is the public support to reduce the expansion of this viral infection. 


\section{Acknowledgement}

The authors are grateful to the head Department of Zoology for providing necessary internet and communication facility and also wish to acknowledge World health Organization and Worldometer Coronavirus site for ready availability of data in the public domain.

\section{Conflict of Interest}

The authors declare that there is no conflict of interest to disclose.

\section{Funding Information}

The work was carried out without any funding. However, the first author is working under DBT-sponsored project as Senior Research Fellow.

\section{References}

1. Kahn JS, McIntosh K. History and recent advances in coronavirus discovery. Pediatr Infect Dis J. 2005; 24: S223-S226. doi:10.1097/01.inf.0000188166.17324.60

2. Geller C, Varbanov M, Duval RE. Human coronaviruses: insights into environmental resistance and its influence on the development of new antiseptic strategies. Viruses. 2012; 4: 3044-3068. doi:10.3390/v4113044

3. de Groot RJ, Baker SC, Baric R, Enjuanes L, Gorbalenya AE, Holmes KV, Perlman S, Poon L, Rottier PJ, Talbot PJ, Woo PC, Ziebuhr J. Family Coronaviridae. In King AM, Lefkowitz E, Adams MJ, Carstens EB, International Committee on Taxonomy of Viruses, International Union of Microbiological Societies. Virology Division (eds.). Ninth Report of the International Committee on Taxonomy of Viruses. Oxford: Elsevier. 2011, pp. 806-28. ISBN 978-012-384684-6.

4. International Committee on Taxonomy of Viruses (201008-24). "ICTV Master Species List2009-v10" (http:// talk.ictvonline.org/files/ictv_documents/m/msl/1231/ download.aspx) (xls).

5. Belouzard S, Millet JK, Licitra BN, Whittaker GR. Mechanisms of Coronavirus Cell Entry Mediated by the Viral Spike Protein. Viruses. 2012; 4: 10111033. doi:10.3390/v4061011 \

6. Yang H, Bartlam M, Rao Z. Drug design targeting the main protease, the Achilles' heel of coronaviruses. Curr Pharm Des. 2006; 12: 4573-90. https://doi. org/10.2174/138161206779010369
7. Woo PC, Huang Y, Lau SK, Yuen KY. Coronavirus genomics and bioinformatics analysis. Viruses. 2010; 2:1804-20. https://doi.org/10.3390/v2081803

8. Sexton NR, Smith EC, Blanc H, Vignuzzi M, Peersen OB, Denison MR. (2016). Homology-Based Identification of a Mutation in the Coronavirus RNA-Dependent RNA Polymerase That Confers Resistance to Multiple Mutagens. J Virol. 2016; 90:7415-7428. doi:10.1128/jvi.00080-16

9. Fehr AR, Perlman S: Maier HJ, Bickerton E, Britton P (eds.). "Coronaviruses: an overview of their replication and pathogenesis" Methods in Molecular Biology. 2015, Springer. 1282; 1-23. doi: 10.1007/978-1-4939-2438-7_1

10. ICTV Virus Taxonomy: 2018 Release. 2018. Available online: https://talk.ictvonline.org/taxonomy/(accessed on 28 January 2019).

11. Chang CK, Lo SC, Wang YS, Hou MH. Recent insights into the development of therapeutics against coronavirus diseases by targeting N protein. Drug Discov Today. 2016; 21: 562-572. https://doi.org/10.1016/j.drudis.2015.11.015

12. Paules CI, Marston HD, Fauci AS: Coronavirus infectionsmore than just the common cold. JAMA. 2020. https://doi. org/10.1001/jama.2020.0757

13. Wu Z, Yang L, Ren X, He G, Zhang J, Yang J, et al: Deciphering the bat virome catalog to better understand the ecological diversity of bat viruses and the bat origin of emerging infectious diseases. ISME J. 2016; 10:609-620. doi: 10.1038/ismej.2015.138

14. Fan Y, Zhao K, Shi ZL, Zhou P: Bat Coranaviruses in China. Viruses. 2019; 11: 210-223; doi: 10.3390/v11030210

15. Drosten C, Gunther S, Preiser W, van der Werf S, Brodt HR, Becker S, Rabenau H, et al. Identification of a novel coronavirus in patients with severe acute respiratory syndrome. N Engl J Med. 2003; 348: 1967-1976. https://doi. org/10.1056/NEJMoa030747

16. Peiris JSM, Lai ST, Poon L, et al. Coronavirus as a possible cause of severe acute respiratory syndrome. Lancet. 2003; 361 : 1319-1325. https://doi.org/10.1016/S0140-6736(03)13077-2

17. Saif LJ. Animal coronaviruses: what can they teach us about the severe acute respiratory syndrome? Rev Sci Techno.l 2004; 23: 643-660. https://doi.org/10.20506/rst.23.2.1513

18. Zaki AM, van Boheemen S, Bestebroer TM, Osterhaus AD, Fouchier RA. Isolation of a novel coronavirus from a man with pneumonia in Saudi Arabia. N Engl J Med. 2012; 367: 1814-1820. https://doi.org/10.1056/NEJMoa1211721

19. Wang C, Horby PW, Hayden FG, Gao GF. A novel coronavirus outbreak of global health concern. Lancet. 2020; https://doi.org/10. 1016/S0140-6736(20)30185-9.

20. Zhou P, Yang XL, Wang XG, Hu B, Zhang L, Zhang W, Si HR, Zhu Y, Li B, Huang CL, et al. A pneumonia outbreak associated with a new coronavirus of probable bat origin. Nature. 2020; https://doi.org/10.1038/s41586-020-2012-7. 
21. Zhu N, Zhang D, Wang W, Li X, Yang B, Song J, Zhao X, Huang B, Shi W, Lu R, et al. A Novel Coronavirus from Patients with Pneumonia in China, 2019. NEngl J Med. 2020; 382: 727-733. https://doi.org/10.1056/NEJMoa2001017

22. Singhal T. A Review of Coronavirus Disease-2019 (COVID19). Indian J Pediatr. 2020; 87: 281-286. https://doi.org/ 10.1007/s12098-020-03263-6

23. Imperial College London. Report 2. estimating the potential total number of novel coronavirus cases in Wuhan City, China. Jan 2020. https://www.imperial.ac.uk/mrcglobalinfectiousdisease-analysis/news--wuhan-coronavirus.

24. Xinhua. China's CDC detects a large number of new coronaviruses in the South China seafood market in Wuhan. Available at: https:// www.xinhuanet.com/202001/27/c_1125504355.htm. Accessed 20 Feb 2020

25. Huang C, Wang Y, Li X, et al. Clinical features of patients infected with 2019 novel coronavirus in Wuhan, China. Lancet. 2020; 395: 497-506. https://doi.org/10.1016/S01406736(20)30183-5

26. Li Q, Guan X, Wu P, et al. Early transmission dynamics in Wuhan, China, of novel coronavirus-infected pneumonia. NEnglJMed. 2020; https://doi.org/10.1056/NEJMoa2001316

27. Millet JK, Whittaker GR. Physiological and molecular triggers for SARS-CoV membrane fusion and entry into host cells. Virology. 2018; 517: 3-8. doi:10.1016/j. virol.2017.12.015

28. Nash TC, Buchmeier MJ. Entry of mouse hepatitis virus into cells by endosomal and nonendosomal pathways. Virology. 1997; 233: 1-8. https://doi.org/10.1006/viro.1997.8609

29. Matsuyama S, Ujike M, Morikawa S, Tashiro M, Taguchi F. Protease-mediated enhancement of severe acute respiratory syndrome coronavirus infection Proc Natl Acad Sci. 2005; 102: 12543-12547. https://doi.org/10.1073/ pnas.0503203102

30. Kubo H, Yamada YK, Taguchi F. Localization of neutralizing epitopes and the receptor-binding site within the aminoterminal 330 amino acids of the murine Coronavirus spike protein. J Virol. 1994; 68: 5403-5410. https://doi. org/10.1128/JVI.68.9.5403-5410.1994

31. Cheng PK, Wong DA, Tong LK, Ip SM, Lo AC, Lau CS, Yeung EY, Lim WW. Viral shedding patterns of coronavirus in patients with probable severe acute respiratory syndrome. Lancet. 2004; 363: 1699-1700. https://doi. org/10.1016/S0140-6736(04)16255-7

32. Simmons G, Zmora P, Gierer S, Heurich A, Pöhlmann S. Proteolytic activation of the SARS-coronavirus spike protein: cutting enzymes at the cutting edge of antiviral research. Antivir Res. 2013; 100: 605-14. doi:10.1016/j. antiviral.2013.09.028

33. Zhang QF, Cui JM, Huang XJ, Lin W, Tan DY, Xu JW, Zheng HY. Morphology and morphogenesis of severe acute respiratory syndrome (SARS)-associated virus. Acta Biochimica et Biophysica Sinica-Chinese edition 2003; 35: 587-591.

34. Qinfen Z, Jinming C, Xiaojun H, Huanying Z, Jicheng H, Ling F, Jingqiang $Z$. The life cycle of SARS coronavirus in Vero E6 cells. J Med Virol. 73: 332-337. https://doi. org/10.1002/jmv.20095

35. Zhou P, Fan H, Lan T, Yang XL, Shi WF, Zhang W, et al. Fatal swine acute diarrhoea syndrome caused by an HKU2related coronavirus of bat origin. Nature. 2018: 556: 255-258. doi: 10.1038/s41586-018-0010-9

36. Shi J, Wen Z, Zhong G, Yang H, et al. Susceptibility of ferrets, cats, dogs, and other domesticated animals to SARS-coronavirus 2. Science. doi: 10.1126/science. abb7015

37. Lam TT, Shum MH, Zhu H, et al. Identifying SARS-CoV-2 related coronaviruses in Malayan pangolins. Nature. 2020; https://doi.org/10.1038/s41586-020-2169-0

38. Guan Y, Zheng BJ, He YQ, Liu XL, Zhuang ZX, Cheung CL, Luo SW, Li PH, Zhang LJ, Guan YJ, et al. Isolation and characterization of viruses related to the SARS coronavirus from animals in southern China. Science. 2003; 302: 276278. https://doi.org/10.1126/science.1087139

39. Kan B, Wang M, Jing H, Xu H, Jiang X, Yan M, Liang W, Zheng H, Wan K, Liu Q, et al. Molecular evolution analysis and geographic investigation of severe acute respiratory syndrome coronavirus-like virus in palm civets at an animal market and on farms. J Virol. 2005; 79: 11892-11900. https://doi.org/10.1128/JVI.79.18.11892-11900.2005

40. Wang M, Yan M, Xu H, Liang W, Kan B, Zheng B, Chen $\mathrm{H}$, Zheng $\mathrm{H}, \mathrm{Xu} \mathrm{Y}$, Zhang E, et al. SARS-CoV infection in a restaurant from palmcivet. Emerg Infect Dis. 2005; 11:1860-1865. https://doi.org/10.3201/eid1112.041293

41. Memish ZA, Mishra N, Olival KJ, Fagbo SF, Kapoor V, Epstein JH, Alhakeem R, Durosinloun A, Al Asmari $\mathrm{M}$, Islam A, et al. Middle East respiratory syndrome coronavirus in bats, Saudi Arabia. Emerg Infect Dis. 2013; 19: 1819-1823. https://doi.org/10.3201/eid1911.131172

42. Haagmans BL, Al Dhahiry SH, Reusken CB, Raj VS, Galiano M, Myers R, Godeke GJ, Jonges M, Farag E, Diab A, et al. Middle East respiratory syndrome coronavirus in dromedary camels: an outbreak investigation. Lancet Infect Dis. 2014; 14: 140-145. https://doi.org/10.1016/S14733099(13)70690-X

43. Yin Y, Wunderink RG. MERS, SARS and other coronaviruses as causes of pneumonia. Respirology. 2017; 23: 130-137. doi:10.1111/resp.13196

44. Li W, Shi Z, Yu M, Ren W, Smith C, Epstein JH, Wang H, Crameri G, Hu Z, Zhang H, et al. Bats are natural reservoirs of SARS-like coronaviruses. Science. 200; 310: 676-679. https://doi.org/10.1126/science. 1118391 
45. Ge XY, Li JL, Yang XL, Chmura AA, Zhu G, Epstein JH, Mazet JK, Hu B, Zhang W, Peng C, et al. Isolation and characterization of a bat SARS-like coronavirus that uses the ACE2 receptor. Nature. 2013; 503: 535-538. https:// doi.org/10.1038/nature12711

46. Yang XL, Hu B, Wang B, Wang MN, Zhang Q, Zhang W, Wu LJ, Ge XY, Zhang YZ, Daszak P, et al. Isolation and Characterization of a Novel Bat Coronavirus Closely Related to the Direct Progenitor of Severe Acute Respiratory Syndrome Coronavirus. J Virol. 2015; 90: 3253-3256. https://doi.org/10.1128/JVI.02582-15

47. Hu B, Zeng LP, Yang XL, Ge XY, Zhang W, Li B, Xie JZ, Shen XR, Zhang YZ, Wang N, et al. Discovery of a rich gene pool of bat SARS related coronaviruses provides new insights into the origin of SARS coronavirus. PLoS Pathog. 2017; 13:e1006698. https://doi.org/10.1371/ journal.ppat.1006698

48. Sahin AR, Erdogan A, Mutlu Agaoglu P, Dineri Y, Cakirci AY, Senel ME, et al. 2019 Novel Coronavirus (COVID19) Outbreak: A Review of the Current Literature. EJMO. 2020; 4: 1-7. https://doi.org/10.14744/ejmo.2020 .12220

49. Gralinski LE, Menachery VD. Return of the Coronavirus: 2019-nCoV. Viruses. 2020; 12: 135. https://doi.org/10.3390/ v12020135

50. Seven days in medicine: 8-14 Jan 2020. BMJ. 2020; 368:m132.31948945

51. Chan JFW, Yuan S, Kok KH, To KKW, Chu H, Yang J, Xing F, Liu J, Yip CCY, Poon RWS, Tsoi HW. A familial cluster of pneumonia associated with the 2019 novel coronavirus indicating person-to-person transmission: a study of a family cluster. Lancet. 2020. https://doi.org/10.1016/S01406736(20)30154-9

52. Rapoport B. Pathophysiology of Hashimoto's thyroiditis and hypothyroidism. Annu Rev Med. 1991; 42: 91-96. doi:10.1146/annurev.me.42.020191.000515.

53. Duan SM, Zhao XS, Wen RF, Huang JJ, Pi GH, Zhang SX, et al. Stability of SARS coronavirus in human specimens and environment and its sensitivity to heating and UV irradiation. Biomed Environ Sci. 2003; 16: 246-255.

54. Greatorex JS, Digard P, Curran MD, Moynihan R, Wensley $\mathrm{H}$, Wreghitt T, et al. Survival of influenza $\mathrm{A}(\mathrm{H} 1 \mathrm{~N} 1)$ on materials found in households: implications for infection control. PLoS One. 2011; 6: e27932. doi:10.1371/journal. pone. 0027932

55. Fernstrom A, Goldblatt M. Aerobiology and its role in the transmission of infectious diseases. J Pathog. 2013; 493960. doi:10.1155/2013/493960

56. Nikitin N, Petrova E, Trifonova E, Karpova O. Influenza virus aerosols in the air and their infectiousness. Adv Virol. 2014; 859090. doi:10.1155/2014/859090
57. Warnes SL, Little ZR, Keevil CW: Human Coronavirus 229E Remains Infectious on Common Touch Surface Materials. mBio. 2015; 6: e01697-01615. doi:10.1128/mBio.01697-15

58. Marr LC, Tang JW, Van Mullekom J, Lakdawala SS. Mechanistic insights into the effect of humidity on airborne influenza virus survival, transmission and incidence. J R Soc Interface. 2019; 16: 20180298. doi:10.1098/rsif.2018.0298

59. Guo YR, Cao QD, Hong ZS, Tan YY, Chen SD, Jin HJ, et al. The origin, transmission and clinical therapies on coronavirus disease 2019 (COVID-19) outbreak - an update on the status. Mil Med Res. 2020; 7: 11. doi: 10.1186/ s40779-020-00240-0

60. Frieden TR, Lee CT. Identifying and Interrupting Superspreading Events-Implications for Control of Severe Acute Respiratory Syndrome Coronavirus 2. Emerg Infect Dis. 2020; 26. doi:10.3201/eid2606.200495

61. Kampf G, Todt D, Pfaender S, Steinmann E. Persistence of coronaviruses on inanimate surfaces and its inactivation with biocidal agents. J Hosp Infect. 6 Feb 2020. https://doi. org/10.1016/j.jhin.2020.01.022

62. Xia S, Liu M, Wang C, et al. Inhibition of SARS-CoV-2 (previously 2019-nCoV) infection by a highly potent pancoronavirus fusion inhibitor targeting its spike protein that harbors a high capacity to mediate membrane fusion. Cell Res. 2020; 30: 343-355. https://doi.org/10.1038/s41422020-0305-x

63. Loon SC, Teoh SC, Oon LL, Se-Thoe SY, Ling AE, Leo YS, Leong HN. The severe acute respiratory syndrome coronavirus in tears. Brit J Ophthalmol. 2004; 88: 861-863. https://doi.org/10.1136/bjo.2003.035931

64. Rothe C, Schunk M, Sothmann P, Bretzel G, Froeschl G, Wallrauch C, Zimmer T, Thiel V, Janke C. Transmission of EJMO 7 2019-nCoV Infection from an Asymptomatic Contact in Germany, 30.01.2020 https://doi.10.1056/ NEJMc2001468

65. Chen H, Guo J, Wang C, et al. Clinical characteristics and intrauterine vertical transmission potential of COVID-19 infection in nine pregnant women: a retrospective review of medical records. Lancet. 2020; https://doi.org/10.1016/ S0140-6736(20)303 60-3.

66. Chen N, Zhou M, Dong X, Qu J, Gong F, Han Y, Yu T. Epidemiological and clinical characteristics of 99 cases of 2019 novel coronavirus pneumonia in Wuhan, China: a descriptive study. Lancet. 2020a; 395: 507-513. https://doi. org/10.1016/S0140-6736(20)30211-7

67. World Health Organization. Situation reports. Available at: https://www.who.int/emergencies/diseases/novelcoronavirus-2019/ situation-reports/. Accessed 22 Feb 2020.

68. Wu Z, McGoogan JM. Characteristics of and Important Lessons from the Coronavirus Disease 2019 (COVID- 
19) Outbreak in China: Summary of a Report of 72314 Cases From the Chinese Center for Disease Control and Prevention. JAMA. 24 Feb 2020. doi: 10.1001/ jama.2020.2648

69. Yam WC, Chan KH, Poon LL, Guan Y, Yuen KY, Seto WH, Peiris JS. Evaluation of reverse transcription-PCR assays for rapid diagnosis of severe acute respiratory syndrome associated with a novel coronavirus. J Clin Microbiol. 2003; 41(10): 4521-4. doi:10.1128/ jcm.41.10.4521-4524.2003

70. Pan Y, Guan H, Zhou S, Wang Y, Li Q. et al. Initial CT findings and temporal changes in patients with the novel coronavirus pneumonia (2019-nCoV): a study of 63 patients in Wuhan, China. Eur Radiol. 2020; doi: 10.1007/ s00330-020-06731-x

71. Cascella M, Rajnik M, Cuomo A et al. Features, Evaluation and Treatment Coronavirus (COVID-19). StatPearls Publishing, 2020.

72. Chu CM. Role of lopinavir/ritonavir in the treatment of SARS: initial virological and clinical findings. Thorax. 2004; 59: 252-256. doi:10.1136/thorax.2003.012658

73. Zeng LK, Tao XW, YuanWH,Wang J, Liu X, Liu ZS. First case of neonate infected with novel coronavirus pneumonia in China. Zhonghua Er Ke Za Zhi. 2020; 58: E009.

74. Holshue ML, DeBolt C, Lindquist S, et al. First case of 2019 novel coronavirus in the United States. N Engl J Med. 2020; https://doi.org/10.1056/NEJMoa2001191.

75. Sheahan TP, Sims AC, Leist SR, Schafer A, Won J, Brown AJ, Montgomery SA, Hogg A, Babusis D, Clarke MO, et al. Comparative therapeutic efficacy of remdesivir and combination lopinavir, ritonavir, and interferon beta against MERS-CoV. Nat Commun. 2020; 11: 222. https:// doi.org/10.1038/s41467-019-13940-6

76. Derebail VK, Falk RJ. ANCA-Associated VasculitisRefining Therapy with Plasma Exchange and Glucocorticoids. Mass Medical Soc. 2020. https://doi. org/10.1056/NEJMe1917490

77. Gautret P, Lagier JC, Parola P, et al. Hydroxychloroquine and azithromycin as a treatment of COVID-19: results of an open-label non-randomized clinical trial. Int J Antimicrob Agents. 2020; 105949. [PMID: 32205204] doi:10.1016/j. ijantimicag.2020.105949

78. Researchers find two drugs that can effectively inhibit coronavirus - CGTN." [Online]. Available: https://news.
cgtn.com/news/2020-02-04/Researchers-find-two-drugsthat-can-effectively-inhibit-coronavirus-NOFpci7NJK/ index.html. [Accessed: 28-Apr-2020].

79. McKay BLP. Drugmakers rush to develop vaccines against china virus the wall street journal. [cited 202028 January]; Available from: https://www.wsj.com/articles/drugmakersrushto-develop-vaccines-against-china-virus-11579813026

80. Dong L, Hu S, Gao J. Discovering drugs to treat coronavirus disease 2019 (COVID-19)," Drug Discov Ther. 2020; 14: 58-60. doi: 10.5582/ddt.2020.01012

81. Mair-Jenkins J, Saavedra-Campos M, Baillie JK, Cleary P, Khaw FM, et al. The Effectiveness of Convalescent Plasma and Hyperimmune Immunoglobulin for the Treatment of Severe Acute Respiratory Infections of Viral Etiology: A Systematic Review and Exploratory Meta-analysis. J Infect Dis. 2014; 211: 80-90. doi:10.1093/infdis/jiu396

82. Koenig K. Identify-Isolate-Inform: A Modified Tool for Initial Detection and Management of Middle East Respiratory Syndrome Patients in the Emergency Department. West J Emerg Med. 2015; 16: 619-624. doi:10.5811/westjem.2015.7.27915

83. Tian X, Li C, Huang A, Xia S, Lu S, et al. Potent binding of 2019 novel coronavirus spike protein by a SARS coronavirusspecific human monoclonal antibody. Emerg Microbes Infect. 2020; 9: 382-385. doi:10.1080/22221751.2020.1729069

84. Zhang L, Liu Y. Potential interventions for novel coronavirus in China: A systematic review," J M Virol. 2020; 92: 479-490. doi: 10.1002/jmv.25707

85. Cheung E. China coronavirus: Hong kong researchers have already developed vaccine but need time to test it, expert reveals: South china morning post. [cited 202029 January]; Available from: https://www.scmp.com/news/hongkong/ health environment/article/3047956/chinacoronavirushong-kong-researchers-have.

86. Lee LZ. Chinese scientists race to develop vaccine as coronavirus death toll jumps: South china morning post. [cited 202029 January]; Available from: https://www.scmp.com/news/china/society/article/ 3047676/numbercoronavirus-cases chinadoubles- spreadrate-accelerates.

87. Cally L, Druce JD, Catton MG, Jans DA, Wagstaff KM. The FDA-approved Drug Ivermectin inhibits the replication of SARS-CoV-2 in vitro. Antivir Res. 2020; https://doi. org/10.1016/j.antiviral.2020.104787 